\title{
Phytoremediation of heavy metal from leachate using imperata cylindrica
}

\author{
Khairul Anam Moktar, ${ }^{1, *}$, and Ramlah Mohd Tajuddin ${ }^{2}$ \\ ${ }^{1}$ Faculty of Civil Engineering, Universiti Teknologi MARA, Shah Alam, Malaysia \\ ${ }^{2}$ Associate Professor, Faculty of Civil Engineering, Universiti Teknologi MARA, Shah Alam, Malaysia
}

\begin{abstract}
Landfill leachate has many toxic substances, which may adversely affect the environmental health. The high concentration of heavy metal in landfill leachate creates complication to its removal and management. Hence this research was conducted to explore the ability of phytoremediation using Imperata cylindrica to remove Lead, Zinc and Cadmium; which is deemed to be nature friendly and sustainable. Raw landfill leachates were taken from the collection ponds at Jeram Sanitary Landfill and placed in fabricated phytoremediation system at UiTM laboratory. Heavy metal concentration of leachate from this system was monitored for 30 days. It was found that Imperata cylindrica is able to remove lead, Zinc and Cadmium from the leachate.
\end{abstract}

\section{Introduction}

Landfill leachate is highly concentrated and a complex effluent; which contains organic and inorganic compound. The unselective treatment can lead to a major health problem globally as the inorganic compound such as heavy metal cannot be degraded or changed to nontoxic form easily [1].

The exposure of heavy metals can cause disorder to human and other living organisms. Additionally, this type of pollutants has the potential to contribute in mortality and increase the serious irreversible illness. Acute poisoning in human can cause severe failure in the kidneys, reproductive system, liver, brain and nervous system.

As leachate vary so much even within landfills, at present a universal solution to the problem had not been found. Numerous methods have been introduced for removing heavy metals from leachate mainly, chemical precipitation, chemical oxidation or reduction, ultrafiltration, electrochemical treatment, reverse osmosis, electro-dialysis, application of membrane technology, evaporation recovery, solvent extraction and ion exchange process.

Although, above-mentioned methods had proven to remove the pollutants but those are very expensive and may produce large volume of wastes and not economically feasible for small and medium size landfill. However, methods are continuously reviewed and developed to meet this environmental issue [14].

Treatments within the recycling, filtering, filtering, biological and chemical areas are the most common [14], but phytoremediation-the use of plant in the purifying process- has gained attention as a viable option for landfills.
Phytoremediation is a treatment that uses plants to remediate heavy metals from contaminated water and wastewater; it is reported that that the pollutants are confined within the root zone of the plant [2] [3]. Hence phytoremediation has become an operational and affordable technological solution used to extract or remove metal pollutants from wastewater and soil.

Many plants have successfully absorbed contaminants such as lead, cadmium, chromium, arsenic and various radionuclides from wastewater. One of the phytoremediation categories is phytoextraction, which can be used to remove heavy metals from leachate using its ability to uptake metals which is essential for plant growth (Fe, Mn, $\mathrm{Zn}, \mathrm{Cu}, \mathrm{Mo}$ and Ni). These studies proved that phytoremediation is a potential or an alternative approach to treat heavy metals such as Cadmium (Cd), Lead $(\mathrm{Pb})$, and Zinc $(\mathrm{Zn})$ contaminated site.

Table 1 shows the options of phytoremediation process available and their specific contaminants removal. This table presented several types of phytoremediation process and types which can be used as potential technique for phytoremediation to remove treat heavy metals such as $(\mathrm{Cd})$, Lead $(\mathrm{Pb})$, and Zinc $(\mathrm{Zn})$ from contaminated site [2] [3]. 
Table 1. Phytoremediation process options [2][3]

\begin{tabular}{|c|c|c|c|}
\hline Process & Mechanism & Media & $\begin{array}{c}\text { Contaminant } \\
\mathrm{s}\end{array}$ \\
\hline $\begin{array}{l}\text { Phyto- } \\
\text { Extraction }\end{array}$ & $\begin{array}{c}\text { Hyper- } \\
\text { Accumulator }\end{array}$ & $\begin{array}{c}\text { Soil, } \\
\text { Brownfield } \\
\text { Sediments }\end{array}$ & $\begin{array}{c}\text { Metals (Pb, } \\
\mathrm{Cd}, \mathrm{Zn}, \mathrm{Ni} \text {, } \\
\mathrm{Cu}) \text { With } \\
\text { Edta } \\
\text { Addition For } \\
\mathrm{Pb} \text {, Selenium }\end{array}$ \\
\hline $\begin{array}{l}\text { Rhizo- } \\
\text { Filtration }\end{array}$ & $\begin{array}{l}\text { Rhizosphere } \\
\text { Accumulation }\end{array}$ & $\begin{array}{c}\text { Groundwat } \\
\text { er, Water } \\
\text { And } \\
\text { Wastewate } \\
\text { r Lagoons } \\
\text { Or } \\
\text { Wetlands }\end{array}$ & $\begin{array}{c}\text { Metals }(\mathrm{Pb}, \\
\mathrm{Cd}, \mathrm{Zn}, \mathrm{Ni}, \\
\mathrm{Cu}) \\
\text { Radionuclide } \\
\text { s, } \\
\text { Hydrophobic } \\
\text { Organics } \\
\end{array}$ \\
\hline $\begin{array}{c}\text { Phyto- } \\
\text { Stabilizati } \\
\text { on }\end{array}$ & Complexation & $\begin{array}{l}\text { Soil And } \\
\text { Sediments }\end{array}$ & $\begin{array}{c}\text { Metals }(\mathrm{Pb}, \\
\mathrm{Cd}, \mathrm{Zn}, \mathrm{Ni}, \\
\mathrm{Cu}, \mathrm{Cr}, \mathrm{Se}) \text {, } \\
\text { Hydrophobic } \\
\text { Organics } \\
\text { (Pahs, Pcbs, } \\
\text { Dioxin, } \\
\text { Furan, Ddt) }\end{array}$ \\
\hline $\begin{array}{l}\text { Phyto- } \\
\text { Volitilizat } \\
\text { ion }\end{array}$ & $\begin{array}{l}\text { Volitilization } \\
\text { By Leaves }\end{array}$ & $\begin{array}{c}\text { Soil, } \\
\text { Groundwat } \\
\text { er And } \\
\text { Sediments }\end{array}$ & $\begin{array}{c}\text { Mercury, } \\
\text { Selenium, } \\
\text { Tritium }\end{array}$ \\
\hline $\begin{array}{l}\text { Phyto- } \\
\text { Degradati } \\
\text { on }\end{array}$ & $\begin{array}{l}\text { Degradation } \\
\text { In Plant }\end{array}$ & $\begin{array}{c}\text { Soil, } \\
\text { Groundwat } \\
\text { er, Landfill } \\
\text { Leachate, } \\
\text { Land } \\
\text { Applicatio } \\
\text { n Of } \\
\text { Wastewate } \\
\text { r } \\
\end{array}$ & $\begin{array}{c}\text { Herbicides, } \\
\text { Btex, Tce, } \\
\text { Ammunition } \\
\text { Waste }\end{array}$ \\
\hline
\end{tabular}

\section{Experimental Procedures}

\subsection{Leachate site selection}

Raw landfill leachates were sampled from the collection ponds at Jeram Sanitary Landfill, Selangor, Malaysia; which has 48 hectares of the total operation area with an average of 2100 ton of solid wastes received per day though the design capacity is only for 1250 ton per day with the equivalent of 8 million cubic meter airspace. The leachate sample has been sampled using well sealed bottles in order to minimize the sample from being exposed to oxygen. Leachate sample has been collected in triplicate; in order to get the actual parameters in the leachate pond. In the laboratory, the leachate was characterized using Inductively Coupled Plasma Optical Emission Spectrometry (ICP-OES) (Method 3010B, 3030G, 3125B).

\subsection{Phytoremediation system}

The phyto-floating bed treatment was a batch system fabricated in the Hydrology Laboratory at Universiti Teknologi MARA (UiTM) in Shah Alam and it was conducted at a room temperature as shown in Figure 1. The Phyto-floating bed system was designed to be in a stagnant condition because the procedure was conducted as a bench scale experiment for batch system. The floating platform is made of polystyrene because it will not absorb any liquid or other substance and it was because of the capability to float and act as a buoyancy aid to allow the plants float on the leachate tank. The leachate tank was given adequate ventilation and enough sunlight along the experimental procedures was conducted. The plant was cultured separately in a system $(0.66 \mathrm{~m} \times 0.44 \mathrm{~m} \times 0.35 \mathrm{~m})$ filled with $10 \mathrm{~L}$ of leachate and another tank as a control. Open tank was selected to replicate the actual leachate pond, to allowed natural aeration to the surface of the leachate tank. Volume loss due to evaporation and sampling procedure was countered by adding the same batch of leachate throughout the treatment period.

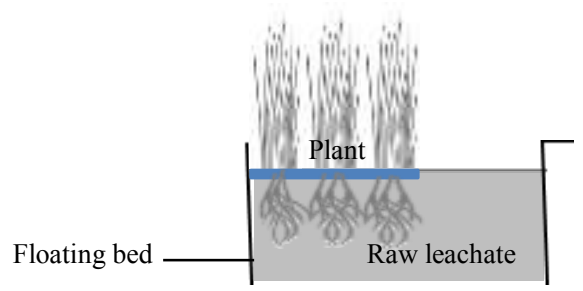

Fig. 1. The phytoremediation system which was fabricated in UiTM laboratory and conducted at room temperature level.

\subsection{Plant selection}

Imperata cylindrica distributed throughout the tropical and temperate regions. Common found throughout the hotter parts, often in damp and weedy areas, both in plain and hills, ascending up to $2300 \mathrm{~m}$ in Himalayas. Massively found along river banks, and cultivated land. The characteristics of Imperata cylindrica was shown in Table 3 below. 
Table 2. The Characteristics of imperata cylindrical [15].

\begin{tabular}{|c|c|c|c|}
\hline Sr. & Part & Component & D. bipinnata \\
\hline \multirow{9}{*}{1} & \multirow{9}{*}{ Root } & Epiblema & Hexagonal cells \\
\hline & & Root hairs & Less in number \\
\hline & & Exodermis & $\begin{array}{l}2 \text { to } 3 \text { layered, lignified } \\
\text { sclerenchymatous }\end{array}$ \\
\hline & & Cortex & Air cavities small in size \\
\hline & & $\begin{array}{l}\text { Passage } \\
\text { cells }\end{array}$ & present \\
\hline & & $\begin{array}{l}\text { Casparian } \\
\text { thickenings }\end{array}$ & More in number \\
\hline & & Pericycle & $\begin{array}{l}\text { Single layered, oval to } \\
\text { hexagonal shaped cells }\end{array}$ \\
\hline & & $\begin{array}{l}\text { Vascular } \\
\text { bundles }\end{array}$ & 5 to 6 vascular bundles \\
\hline & & $\begin{array}{l}\text { Conjunctive } \\
\text { tissue }\end{array}$ & $\begin{array}{l}\text { Less in number and occupies } \\
\text { less area. Located mostly in } \\
\text { the periphery of the vascular } \\
\text { bundles }\end{array}$ \\
\hline \multirow{5}{*}{2} & \multirow{5}{*}{ Stolon } & Epidermis & $\begin{array}{l}\text { Pentagonal to hexagonal } \\
\text { cells. Presence of some } \\
\text { hairs. }\end{array}$ \\
\hline & & Hypodermis & 2 to 3 layered \\
\hline & & Cortex & $\begin{array}{l}\text { Outer vascular bundles are } \\
\text { very few in number and } \\
\text { poorly developed. Cortex } \\
\text { has intercellular spaces like } \\
\text { air cavities }\end{array}$ \\
\hline & & Pericycle & 3 to 5 layered \\
\hline & & $\begin{array}{l}\text { Vascular } \\
\text { bundles }\end{array}$ & 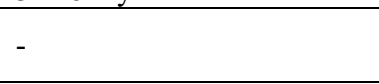 \\
\hline \multirow{4}{*}{3} & \multirow{3}{*}{ Leaf } & epidermis & $\begin{array}{l}\text { Large number of not much } \\
\text { sunken aaaatomata and } \\
\text { presence of bulliform cells }\end{array}$ \\
\hline & & Mesophyll & $\begin{array}{l}\text { Less number of cell occurs } \\
\text { between upper and lower } \\
\text { epidermis. Cells are iso- } \\
\text { diametric }\end{array}$ \\
\hline & & $\begin{array}{l}\text { Vascular } \\
\text { bundle }\end{array}$ & $\begin{array}{l}\text { i. Vascular bundles of nearly } \\
\text { same size except the mid- } \\
\text { rib region } \\
\text { ii. Median portion of lamina } \\
\text { is bulging on the lower } \\
\text { side. }\end{array}$ \\
\hline & & stomata & Alternately arrange stomata \\
\hline
\end{tabular}

Imperata cylindrica distributed throughout the tropical and temperate regions. Common found throughout the hotter parts, often in damp and weedy areas, both in plain and hills, ascending up to $2300 \mathrm{~m}$ in Himalayas. Massively found along river banks, and cultivated land. The characteristics of Imperata cylindrica was shown in Table 3 below.

Imperata cylindrica is equipped with fibrous root structure naturally that has the ability to absorb and extract the nutrient. The root structure growth rate is too much for the leachate pond to make sure that is enough space left for the aeration to help the root system breath and prevent the aerobic condition during the experiment period.

Healthy Imperata cylindrica is obtained from local terrestrial source. These plants are first washed to remove impurities and dirt. The plants were transplanted into floating bed in tank containing $10 \mathrm{~L}$ of raw leachate.
Different number of, Imperata cylindrica were transplant in each tank and differentiated by the length of time for sampling.

The monitoring was performed daily in the span of 30 days. The leachate in each container was sampled on days $0,5,10,15,20,25$ and 30 throughout the experimental period. Throughout the experiment, dead roots and leaf was harvested to avoid the decomposition process and nutrients will be released back into the leachate tank. The characterization of metals in leachate and plant tissue was conducted to measure the strength of the contaminants in the wastewater and the performance of the plant to accumulate the leachate.

Imperata cylindrical had shown good lead remover from contaminated soil. It also yielded moderate biomass. Hence this research is to look into the ability of Imperata cylindrical to remove lead from contaminated water/leachate.

All the analysis was conducted using Perkin Elmer Inc. USA Inductively Coupled Plasma-Atomic Emission Spectrometry. The experiment will be referred to Method 200 [1]. The method starts from the sample preservation process, sample digestion, conducting the analysis and data analysis. Accuracy and precision of the procedures and analysis was verified using reference material (CRM024-050, RTC, Sigma Aldrich, St Louis, U.S.). All samples were prepared and analysed using multi element calibration standard 3 (no $\mathrm{Hg}$ ) by Perkin Elmer Inc. USA [1].

\section{Results}

After the 30 days retention of the leachate, a significant reduction was indicated in the tank. The reduction of $\mathrm{pH}$ shows that the plants have converted the alkalinity of the leachate into a slightly neutral $\mathrm{pH}$ reading. Similar results were also reported by others such as [4], [5] and [6].

The COD and BOD level also has a reduction throughout the experiment (Figure 6). The presence of plants in the leachate depletes as $\mathrm{CO} 2$ dissolved during photosynthetic activities which favours aerobic bacterial to reduce BOD and COD that has been reported by [6], which improve $\mathrm{DO}$ in the leachate treatment pond.

These values were placed alongside WHO guideline values and Environmental Quality Regulations 2009, Malaysia. The mean of $\mathrm{pH}$ in the leachate treatment which was faintly alkaline (8.34) slightly reduced after the treatment towards neutral. The physical parameter of the untreated leachate which was higher than WHO limit was reduced by $97.96 \%$ after the treatment. Total suspended solids reading was reduced by $98.11 \%$ below the initial concentration in the leachate.

Dissolved oxygen which was completely absent in the untreated leachate went up to $1.50 \mathrm{mg} / 1$ after the 30 days treatment. This happened because of the sedimentation and settlement of the colloids during the experiment. 
Table 3. Leachate characteristics from Jeram Landfill.

\begin{tabular}{|c|l|c|c|}
\hline $\begin{array}{c}\text { Test } \\
\text { parameters }\end{array}$ & \multicolumn{1}{|c|}{ Method } & $\begin{array}{c}\text { Range } \\
\text { values } \\
(\mathbf{m g} / \mathbf{L})\end{array}$ & Standard* \\
\hline $\mathrm{pH}$ & Probe insertion & $8.5 \pm 0.8^{*}$ & $6.0-9.0$ \\
\hline $\mathrm{BOD}$ & APHA 5210 B & $351 \pm 45$ & 20 \\
\hline $\mathrm{COD}$ & APHA 5220 & $1266 \pm 103$ & 400 \\
\hline Total N & ASTM E778-87 & $0.75 \pm 0.08^{*}$ & 5 \\
\hline Total K & ASTM E926-94 & $34.8 \pm 2.1$ & N.A \\
\hline Total P & ASTM D5198-92 & $72.9 \pm 0.7$ & N.A \\
\hline $\mathrm{Cu}$ & USEPA 3050 B & $0.5 \pm 0.1$ & 0.2 \\
\hline $\mathrm{Zn}$ & USEPA 3050 B & $6.83 \pm 3$ & 2.0 \\
\hline $\mathrm{Pb}$ & USEPA 3050 B & 2.66 & 0.10 \\
\hline $\mathrm{Cd}$ & USEPA 3050 B & $10.25 \pm 2.5$ & 0.01 \\
\hline
\end{tabular}

(Mean values $n=3$ )

*Environmental Quality Regulations 2009, Malaysia

Removal of PB was as high as $56.3 \%$ removal efficiency, followed by $\mathrm{Cd}$ with $16.2 \%$ removal efficiency and $\mathrm{Zn}$ with $6.58 \%$ removal; regardless of the plant density. It has been shown that $\mathrm{Zn}$ indicated the lowest removal rate. The efficiency of removal can be ranked in this order; $\mathrm{Pb}>\mathrm{Cd}>\mathrm{Zn}$. The study shows that the density affects the efficiency of removal. According to [7] and [8], the plants should be adapted or acclimatized to the pollutant prior to the placement onsite; once acclimatized, only then it is placed in the actual site in order to have a better removal rate of the pollutants.

This is due to the raw leachate concentration that has obliged the plants to adapt to heavy metal. However, in this study, it was directly being carried out in the experiment without the acclimatization process. All subjects provide the optimum reading in terms of its removal efficiency at day 10 .

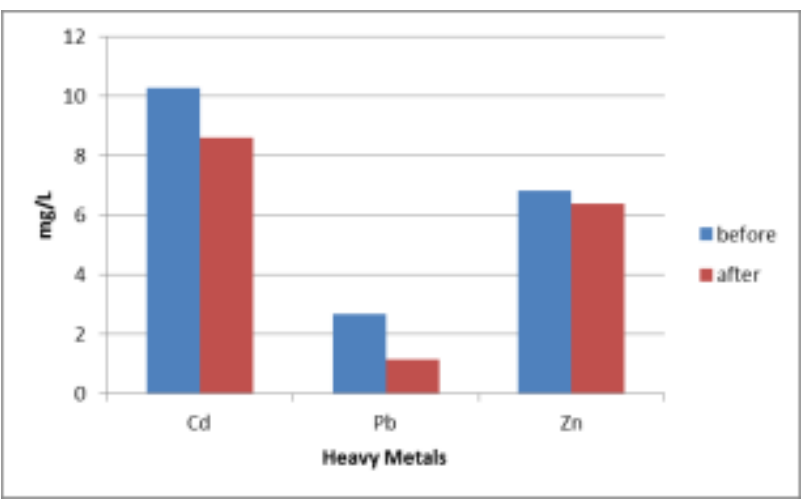

Fig. 2. Reduction of Heavy Metals in the leachates
The reduction of heavy metals is associated to the presence of the plants and uptake during the photosynthetic process for plant to growth during the experimental period; the value for uptake presented the ability of Imperata cylindrica to survive inside leachate solution signifying the accumulation and removal of heavy metals.

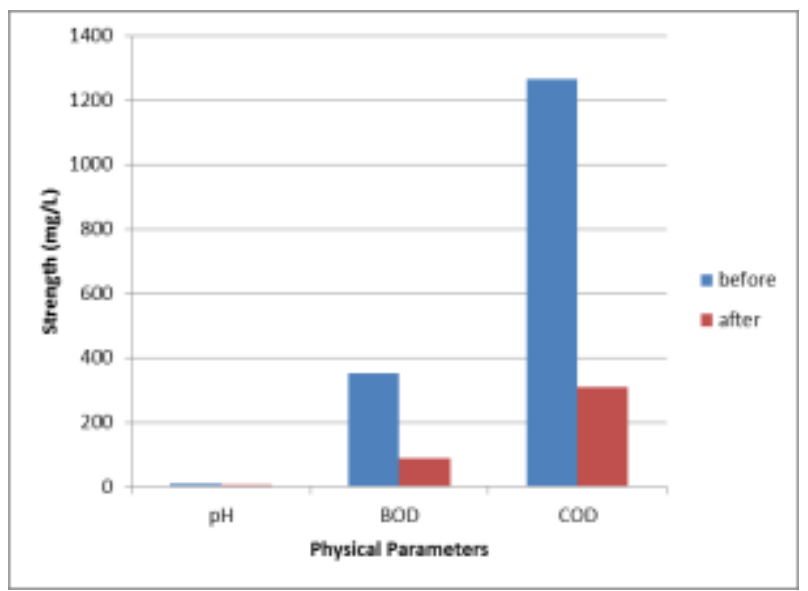

Fig. 3. Reduction of physic-chemical parameters.

Both BOD and COD level was reduce during the experiment; The presence of plants in the leachate depletes dissolve $\mathrm{CO} 2$ during phytosynthetic process which favours aerobic microorganisms to reduce BOD and COD [4]. Ph was slightly adjusted into neutral due to presence of plants and phytoremediation process for the tested leachate tank.

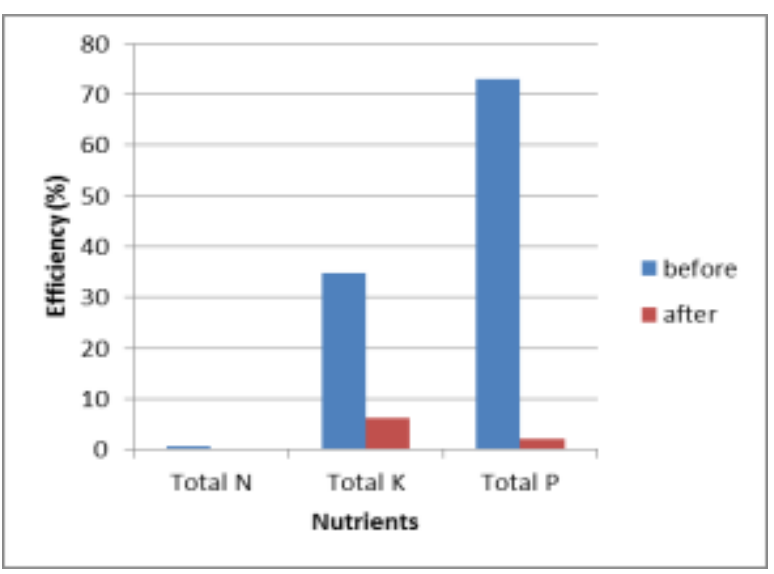

Fig. 4. Nutrient removal in the leachates (\%).

Significant reduce of the nutrient level in leachate is attributed to plant used for growth as reported [6]. It shows that Imperata cylindrica is able to utilize the nutrients for growth beside the heavy metals uptake [6]. 


\subsection{Heavy metal in the plant tissue}

\subsubsection{Heavy metals in root}

In the raw leachate concentration, $\mathrm{Pb}$ has the highest concentration reading which is $2829 \mathrm{mg} / \mathrm{kg}$; followed closely by $\mathrm{Cd}$ at $2620 \mathrm{mg} / \mathrm{kg}$; and $\mathrm{Zn}$ has the lowest content in the root section with $1586 \mathrm{mg} / \mathrm{kg}$. Overall, all the elements have the highest content in the root at day 20 , except for $\mathrm{Zn}$; which was highest at the early stage of the experiment. This suggested that the plant absorbed most of the nutrients such as $\mathrm{Zn}$; as $\mathrm{Zn}$ is responsible for enzyme stimulation for photosynthesis and growth respectively [8-11].

\subsubsection{Heavy metals in shoot}

In the raw leachate concentration, plants indicated the trend of heavy metal content in the shoot section: $\mathrm{Pb}>\mathrm{Cu}>\mathrm{Zn}$. $\mathrm{Pb}$ was recorded the highest concentration at $2341 \mathrm{mg} / \mathrm{kg}$ in the shoot section as recorded at 72 hours (since the start of the experiment) instead of $\mathrm{Cd}$ and $\mathrm{Zn}$ with $690 \mathrm{mg} / \mathrm{kg}$ and $484 \mathrm{mg} / \mathrm{kg}$, respectively, at the early stage of the experiment.

\subsubsection{Heavy metal accumulation}

From the experiment, it clearly shows that the metal content was recorded; essentially in the root section as compared to the shoot section. The plant has the ability to take up a high amount of heavy metal contents in the root section. However, not much is being transported to the shoot section. Most of the contaminants have been used for enzymatic reactions during photosynthesis.

Besides, from the observation, the plants has grown some new hairy roots and new shoots; although, the colour of the leaves start to change at day 16 during the experiment. The changes are not drastically and too obvious. It could be the effects of the transplanted procedure from the ordinary soil and aquifer medium into liquid and slimy medium to survive for growth and photosynthesis process.

The ability to translocate into the shoot is not affected by the heavy metal level in the leachate. The experiment has proven that the shoot section of the plant is not affected by the heavy metals or contaminants even with its translocation ability, thus, allowing the shoots to be used after the treatment without any harmful effects on the environment.

According to the observation and results, presuming that the more plant mass and various plants and accumulator use for phytoremediation treatment, the better result for the effluent released for leachate treatment process and could shorten the treatment and retention time.

\section{Conclusion}

Imperata cylindrica accumulated higher in the roots than shoots. The accumulation for all the heavy metals subjected in this study indicated and exhibited as good $\mathrm{Cd}, \mathrm{Pb}$ and $\mathrm{Zn}$ phyto-extraction properties when grown with leachate. The leachate often contains a high concentration of organic matter and inorganic ions, including nutrients and heavy metals.

Treatment of leachate is an important aspect in solid waste management and treatment system. Leachate can cause significant environmental damage and become a major pollution hazard as it comes into contact with the environment and water bodies. The result depicted that phytoremediation treatment is a promising solution for leachate treatment.

This study shows that the plant is able to take up heavy metal and efficiently reduces the concentration of pollutants in the leachates. It is recommended that the usage of Imperata cylindrica at the surrounding area of leachate collection ponds should be encouraged to prevent the seepage of heavy metals and pollutants from leachates into the aquifers which can result in pollutions to ground water or water bodies during runoff or discharge. This treatment process is a suitable ecotechnology due to reduce footprint, energy savings and increased quality effluent.

A combination of terrestrial hyper-accumulator and remediation plant could be introduced by using this floating-bed method for future research to produce a better result for the sake of leachate treatment.

\section{References}

1. B. Jayanthi, C. U. Emenike, P. Agamuthu, and S. H. Fauziah, "Potential of Cordyline sp Plat for Remediation of Metal-Leachate Contaminated Soil" International Journal of Chemical Engineering and Applications, 8 (2017).

2. A. Garbisu, "Basic concepts on heavy metal soil bioremediation," The European Journal of Mineral Processing and Environmental Protection, 3, 58-66, (2003).

3. Dipu, S., Kumar, A. A And Thanga, V. S. G. Phytoremediation Of Dairy Effluent By Constructed Wetland Technology., Environmentalist; 31, 263-278, (2011).

4. Mahmood, Q., Zheng, P., Islam, E., Hayat, y., Hassan, M.J., Jilani, G. and Jin, R. C. Lab scale studies on water hyacinth (Eicchorniacrassipes mart solms) for biotreatment of textile waste water. Caspian J. Env.Sci., 3, 83-88, (2005).

5. Ugya, A. Y. The efficiency of Lemna minor L. in the phytoremediation of Romi stream: A case study of Kaduna refinery and petrochemical company polluted stream. J. Applied Biol. Biotechnol., 3, 11-14, (2015).

6. Adamu Yunusa Ugya, Agamuthu Priatamby. Phytoremediation of Landfill Leachates Using Pistia Stratiotes: A Case Study of Kinkinau 
U/Ma'azu Kaduna, Nigeria. American Journal of Biological and Environmental Statistics. 2, 60-63, (2016).

7. Wuana, R.A. \& Okieimen, F.E. Heavy Metals in Contaminated Soils: A Review of Sources, Chemistry, Risks and Best Available Strategies for Remediation.

8. International Scholarly Research Network Ecology, (2011).

9. Lissy, A. M. P. N, and Madhu, B. Dr. G. Removal of heavy metals from waste water using water hyacinth., In: Proc. of the International Conference on Advances in Civil Engineering; 42-47, (2010).

10. Khalil, N.A.N.A. Phytoremediation of Heavy Metals and The Physical Changes of Acacia Mangium Planted in Contaminated Soil from Indah Water Konsortium (IWK). (Unpublished degree dissertation). Universiti Putra Malaysia, Malaysia (2011).

11. G. U. Chibuike and S. C. Obior, "Heavy metal polluted soils: Effect on plants and bioremediation methods," Applied and Environmental Soil Science, 4, 1-12, (2014).

12. Padhi, S. Kumar, Sahu S. Kumar, Kumari Anuradha, BharatiSudha, Ansari Shahbaj. Phytortemediation as an Alternative for Treatment of Paper Industry Effluent by Using Water Hyacinth (Eicchorniacrassipes)-A Polishing Treatment. INT Journal of Research in Chemistry and Environment; 2, 2248-9649, (2012).

13. Gamage, N. S. and Yapa, P. A. J. Use of water hyacinth [Eichhorniacrassipes (Mart) solms] in treatment systems for textile mill effluents - A case study., J. Natn. Sci. Foundation Sri Lanka; 29, 15-28, (2001).

14. Abbas A A, Jingsong G, Ping L Z, Ya P Y, AlRekabi W S. Review on Landfill Leachate Treatments. American Journal of Applied Sciences 6, 672-684 (2009).

15. Niti T. Shah1 et al: Preliminary Pharmacognostic and Phytochemical Evaluation of Kusha (Imperata Cylindrica Beauv). IJAAR Volume III Issue II May-June, 472-482 (2017).

16. Nagendran R, Selvam A, Joseph K, Chiemchaisri C. Phytoremediation and rehabilitation of municipal solid waste landfills and dumpsites: A brief review. Waste Management 26, 1357-1369 (2006).

17. Annie,Melinda,Paz-AlbertoGilbert,C. Igua Bellrose G. BauiJacqueline A. Prudente. Phytoextraction of lead-contaminated soil using vetivergrass (Vetiveria zizanioides L.), cogongrass (Imperata cylindrica L.) and carabaograss (Paspalum conjugatum L.) Environmental Science and Pollution Research - International, 14, 498-504 (2007) 